\title{
Pelaksanaan Tugas dan Wewenang Badan Kehormatan Sebagai \\ Alat Kelengkapan DPRD Dalam Menjaga Martabat dan \\ Kehormatan Anggota DPRD Berdasarkan Kode Etik DPRD. \\ (Study pada DPRD Provinsi Jambi)
}

\author{
NURI EVIRAYANTI, SH
}

\begin{abstract}
Abstrak
Badan Kehormatan sebagai salah satu Alat Kelengakapan DPRD adalah lembaga yang berhubungan dengan masalah kehormatan para wakil rakyat baik di DPR RI maupun di DPRD, lembaga ini dalam keberadaannya untuk menjawab kebutuhan dari adanya arus reformasi yang menuntut adanya perubahan, keberadaan lembaga ini sangat penting dan strategis dalam melaksanakan tugas dan fungsinya guna mewujudkan pemerintahan yang bersih (good and clean governance).

Berdasarkan latar belakang dirumuskan permasalahannya yaitu bagaimanakah tugas dan wewenang badan kehormatan dalam menjaga martabat dan kehormatan anggota DPRD, dan kendala dan upaya badan kehormatan sebagai salah satu alat kelengkapan DPRD dalam penyelesaian pelanggaran kode etik. Tujuan penelitian ini adalah untuk mengetahui tugas dan wewenang badan kehormatan DPRD dalam menjaga martabat dan kehormatan anggota DPRD dan untuk mengetahui kendala dan upaya yang dilakukan badan kehormatan sebagai alat kelengkapan dalam penyelesaian pelanggaran kode etik pada DPRD Provinsi Jambi.

Penelitian ini, bersifat yuridis normatif, Penelitian yuridis normatif dilakukan dengan cara meneliti bahan pustaka atau data sekunder yang meliputi bahan hukum primer, bahan hukum sekunder, dan bahan hukum tertier. Kemudian data tersebut dianalisis secara yuridis kualitataif, artinya tanpa menggunakan rumus akan tetapi disajikan dalam bentuk uraian dan konsep.

Hasil penelitian adalah tugas dan wewenang badan kehormatan dalam menjaga martabat dan kehormatan Anggota DPRD dilaksanakan berdasarkan Undang-undang Nomor 22 tahun 2003 tentang susunan dan kedudukan MPR, DPR, DPD dan DPRD dan berdasarkan undang-undang Nomor 32 tahun 2004 tentang Pemerintahan Daerah dan Peraturan Pemerintah Nomor 53 tahun 2005 tentang perubahan atas Peraturan Pemerintah Nomor 25 tahun 2004 tentang Pedoman dan Penyusunan Peraturan Tata Tertib DPRD kemudian untuk lebih efektif dalam pelaksanaan tugas dan wewenang sedangkan kendala badan kehormatan dalam menjalankan tugas dan fungsinnya memiliki dua hambatan yaitu
\end{abstract}


hambatan internal dan externalsedangkan upaya badan kehormatan dalam mengatasi kendala tersebut adalah meningkatkan pengawasan yang berbasis etika baik secara internal maupu exsternal terhadap anggota DPRD, proaktif terhadap laporan-laporan yang dapat dibertanggungjawabkan dan tidak melakuan intervensi proses peradilan karena tindakan badan kehormatan berada pada wilayah moralitas.

Kata Kunci: Badan Kehormatan DPRD, Tugas dan wewenang, Kode etik

\section{A. PENDAHULUAN}

\section{A1. Latar Belakang}

Penyelenggaraan pemerintahan dalam suatu Negara tidak hanya terdapat di pusat pemerintahan saja. Pemerintah pusat memberikan wewenangnya kepada Pemerintah daerah untuk menyelenggarakan pemerintahannya sendiri, dan di Indonesia yang dimaksud dengan pemerintahan daerah adalah penyelenggaraan urusan pemerintahan oleh pemerintah daerah dan Dewan Perwakilan Rakyat Daerah menurut asas otonomi dan tugas pembantuan dengan prinsip otonomi yang seluasluasnya dalam sistem dan prinsip Negara Kesatuan Republik Indonesia Tahun $1945 .{ }^{1}$

Di Indonesia salah satu institusi yang menunjukkan Pelaksanaan sistem demokrasi tidak langsung adalah Dewan Perwakilan Rakyat Daerah sebagai lembaga perwakilan rakyat daerah selanjutnya disebut dengan DPRD. DPRD yang memegang peranan penting dalam sistem demokrasi, perwakilan tersebut erat kaitannya dengan otonomi daerah. Otonomi Daerah menempatkan DPRD sebagai institusi atau lembaga perwakilan rakyat yang paling berperan dalam menentukan proses demokratisasi di berbagai daerah. Walaupun dalam kenyataannya DPRD masih belum sepenuhnya dapat menjalankan fungsinya dengan baik, bahkan dalam prakteknya DPRD sering mengaburkan makna demokrasi itu sendiri.

Harapan kearah yang lebih baik terhadap pelaksanaan fungsi DPRD diwujudkan dengan berlakunya Undang-Undang Nomor 32 Tahun 2004 tentang Pemerintahan Daerah yang menempatkan DPRD sebagai bagian dari sistem pemerintahan daerah. Optimalisasi peran DPRD sebagai penyalur aspirasi masyarakat dan fungsi legislasi di daerah diharapkan dapat dilaksanakan lebih baik dengan ditetapkannya Undang-Undang Nomor 32 Tahun 2004. Tentunya optimalisasi peran

\footnotetext{
${ }^{1}$ Lihat, Undang-Undang Nomor 32 Tahun 2004 Tentang Pemerintahan Daerah, Pasal 1 Nomor 1.
} 
DPRD dalam hal ini juga harus didukung oleh Pemerintah Daerah sebagai pelaksana kebijakan di daerah otonomi.

Keberadaan dan berfungsinya lembaga perwakilan tersebut, baik di Pusat maupun di Daerah, dari suatu Negara yang menyatakan diri sebagai Negara demokrasi konstitusional sering Pasal 40 UndangUndang Nomor 32 Tahun 2004 menyebutkan bahwa DPRD merupakan lembaga perwakilan rakyat daerah dan berkedudukan sebagai unsur penyelenggara pemerintahan daerah dan merupakan salah satu unsur penyelenggara pemerintahan daerah disamping pemerintah daerah. Dengan demikian DPRD memiliki fungsi utama yaitu:

a. fungsi legislasi, yaitu membentuk peraturan daerah;

b. fungsi anggaran, yaitu menetapkan anggaran;

c. fungsi pengawasan, yaitu melakukan pengawasan terhadap jalannya pemerintahan dan pelaksanaan peraturan perundang-undangan.

Selain tugas dan wewenang tersebut, DPRD melaksanakan tugas dan wewenang lain yang diatur dalam peraturan perundang-undangan. Berdasarkan Pasal 46 Undang-Undang Nomor 32 Tahun 2004. DPRD dalam menjalankan tugas dan wewenangnya, dilengkapi dengan beberapa alat kelengkapan yang terdiri dari :

1. pimpinan;

2. komisi;

3. panitia musyawarah;

4. panitia anggaran;

5. badan kehormatan;

6. alat kelengkapan lain yang diperlukan;

Salah Satu alat kelengkapan DPR dan DPRD adalah Badan Kehormatan yang merupakan lembaga baru di parlemen di Indonesia, awalnya Badan Kehormatan di DPR dan DPRD pada periode sebelumnya diberi nama "Dewan Kehormatan" yang tidak bersifat tetap dan hanya dibentuk bila terdapat kasus dan disepakati untuk menuntaskan suatu kasus yang menimpa anggota DPR dan DPRD. Tepat pada Periode 2004-2009, Badan Kehormatan di Indonesia didisain sebagai alat kelengkapan yang bersifat tetap, artinya Badan Kehormatan merupakan suatu keharusan untuk segera dibentuk di seluruh parlemen di Indonesia, Argumentasi ini didapatkan bila kita menafsirkan Undang-Undang Nomor 22 Tahun 2003 tentang Susunan 
dan Kedudukan MPR, DPR, DPD dan DPRD jo. Undang-Undang Nomor 32 Tahun 2004 tentang Pemerintahan Daerah. ${ }^{2}$

Badan Kehormatan sebagai salah satu alat kelengkapan DPRD baru beberapa tahun belakangan ini muncul ke permukaan dan diberitakan media massa, khususnya setelah era Reformasi bergulir. Karena lembaga ini menyangkut masalah kehormatan para wakil rakyat di DPRD, maka keberadaan Badan Kehormatan DPRD yang selanjutanya disebut BK DPRD menjadi sangat penting, dibandingkan dengan alat kelengkapan DPRD lainnya.

Keberadaan BK ini semula adalah untuk menjawab kebutuhan mengingat era Reformasi berbeda dengan era sebelumnya di zaman Orde Baru, banyak anggota dewan setelah terpilih menjadi anggota legislatif, bekerja seenaknya tanpa ada orang lain yang memperdulikan, apalagi mengawasinya, misalnya jarang berdinas sebagai anggota Dewan dan jarang menghadiri sidang atau rapat-rapat, padahal masalah yang dibahas dalam rapat-rapat itu berkaitan dengan kepentingan konstituennya, yang dalam hal ini adalah rakyat. Kalau pun mereka masuk, paling-paling hanya sekadar mengisi absen dan pergi lagi untuk melakukan kegiatan atau bisnis di tempat lain. Keadaan ini tentu saja akan merusak citra lembaga legislatif di mata publik.

Belakangan ini berbagai pelanggaran kode etik oleh anggota DPR RI maupun anggota DPRD semakin banyak terungkap, mulai dari percaloan, pemerasan, penyalahgunaan kewenangan, sampai permesuman. Untuk menyikapi ini, kewenangan BK DPR dan khususnya BK DPRD perlu diperbesar. Badan Kehormatan DPR RI dan BK DPRD perlu mengubah mekanisme yang selama ini dilakukan dalam menanggapi dugaan penyimpangan etika anggota DPR maupun DPRD dengan tidak lagi bersifat pasif, tetapi bersifat proaktif, terhadap kasus seperti itu, BK DPR maupun BK DPRD perlu bertindak cepat dalam merespons tindakan angota DPR dan DPRD yang diduga menyimpang dari kode etik. Untuk bisa bertindak cepat, ketentuan internalnya BK yang harus terlebih dahulu dirubah. Selama ini, BK baru bertindak setelah menerima pengaduan dari masyarakat dan pimpinan DPR maupun DPRD. Selain pasif, dengan posisi dan peran seperti itu membuat BK tidak responsive. Sementara banyak kasuskasus yang terjadi di sekitar DPR dan DPRD yang publik mengetahui dengan sangat jelas.

Di sisi lain, BK DPR dan BK DPRD juga belum berfungsi secara optimal sehingga makin menambah beban citra DPR dan DPRD.

\footnotetext{
${ }^{2}$ Anom Surya Putra, Mekanisme Kerja Badan Kehormatan, Makalah disampaikan untuk pelatihan Badan Kehormatan oleh LSPPAD, Hotel Mercure Jakarta, 22 April 2006. Hal.1
} 
Padahal, BK diharapkan berperan tidak hanya sekadar menjadi penjaga moral dan integritas anggota DPR dan DPRD, melainkan juga menjadi mekanisme internal untuk menegakkan kode etik DPR.

Saat ini peran BK kembali dipertanyakan, terutama setelah banyak anggota Dewan terlibat dalam berbagai kasus, seperti korupsi maupun suap. Akibatnya, terjadi krisis moral maupun integritas yang kian parah dalam badan aspirasi maupun perwakilan itu. Oleh karena itulah kiranya perlu dikaji bagaimana tugas dan wewenang Badan kehormatan DPRD kendala-kendala dan upaya Badan Kehormatan sebagai alat kelengkapan DPRD dalam rangka menjaga martabat dan kehormatan sesuai dengan kode etik DPRD.

\section{A.2. Permasalahan}

Bagaimana tugas dan wewenang Badan Kehormatan DPRD dalam menjaga Martabat dan kehormatan anggota DPRD ?

1. Bagaimana Kendala Badan Kehormatan DPRD sebagai salah satu alat kelengkapan DPRD dalam penyelesaian pelanggaran kode etik pada DPRD Provinsi Jambi?

2. Bagaimana Kendala Badan Kehormatan DPRD sebagai salah satu alat kelengkapan DPRD dalam penyelesaian pelanggaran kode etik pada DPRD Provinsi Jambi?

\section{A.3. Tujuan Penelitian}

1. Untuk mengetahui tugas dan wewenang Badan Kehormatan DPRD dalam menjaga Martabat dan kehormatan anggota DPRD?

2. Untuk mengetahui kendala dan upaya Badan Kehormatan DPRD sebagai salah satu alat kelengkapan DPRD dalam penyelesaian pelanggaran kode etik pada DPRD Provinsi Jambi ?

\section{A.4. Metode Penelitian}

\section{a. Metode Pendekatan}

Metode pendekatan yang digunakan dalam penelitian ini adalah metode pendekatan yuridis Normatif, karena ruang lingkup penelitian adalah melakukan studi hukum dalam praktek yang selalu dibingkai dengan doktrin-doktrin hukum. Pendekatan yuridis dilakukan dengan menggunakan ketentuan-ketentuan hukum yang berlaku di Indonesia, baik bahan hukum primer maupun bahan hukum sekunder dan juga menggunakan pendapat para ahli di bidang hukum, terutama yang berkaitan dengan masalah penelitian. Penelitian ini juga didukung dengan pendekatan normatif dengan cara meneliti bahan pustaka dengan mempelajari dan menelaah teori-teori, konsep-konsep serta 
peraturan yang berkaitan dengan permasalahan ${ }^{3}$. dan juga pendekatan politik karena DPRD adalah termasuk lembaga politis dalam menjalankan fungsi dan tugasnya.

\section{b. Spesifikasi Penelitian}

Spesifikasi penelitian yang digunakan dalam penelitian ini adalah Deskriptif-Analistis. Bersifat deskriftif, karena penelitian ini dimaksudkan untuk memberikan gambaran secara rinci, sistematis, faktual dan menyeluruh mengenai segala sesuatu yang diteliti. Sedangkan analistis, berarti mengelompokan, menghubungkan dan memberi makna. ${ }^{4}$ dan dalam penelitian ini analitis berarti mengelompokkan, menghubungkan dan memberi makna terhadap data yang berkaitan dengan fungsi dan peranan Badan Kehormatan DPRD. Analisis dari hasil penelitian ini diharapkan dapat memberikan jawaban terhadap permasalahan dalam tulisan ini.

\section{c. Jenis dan Sumber Data}

\section{Jenis Data}

Dalam penelitian ini jenis data yang digunakan dititikberatkan pada data sekunder dan juga didukung dengan data primer untuk menjawab permasalahan pokok yang dikaji dalam penelitian ini. Pengumpulan data sekunder dalam penelitian ini dilakukan melalui studi yang meliputi $^{5}$ :

1. Bahan Hukum Primer, yaitu bahan hukum yang mengikat, seperti peraturan perundang-undangan;

2. Bahan Hukum sekunder, bahan-bahan yang erat kaitannya dengan bahan hukum primer, misalnya buku-buku literatur hukum, hasil-hasil penelitian, hasil karya ilmiah para sarjana.

3. Bahan Hukum Tersier, merupakan bahan hukum yang memberikan informasi tentang bahan hukum primer dan sekunder, seperti kamus, ensiklopedia.

\section{Sumber Data}

Berkaitan dengan penelitian ini maka data yang digunakan yaitu sumber hukum primer dan sumber hukum sekunder. Sumber hukum primer diperoleh dengan wawancara dengan Ketua dan Anggota Badan Kehormatan Dewan Perwakilan Rakyat Daerah (DPRD) Provinsi Jambi. Data yang diminta

\footnotetext{
${ }^{3}$ Soejono Soekamto dan Sri Mamuji, Penelitian Hukum Normatif, Suatu Tinjauan singkat, Cetakan Ke II. Jakarta. Rajawali 1998. Hal.145

4 Bambang Waluyo, Penelitian Hukum Dalam Praktek.Jakarta: Sinar Grafika, 1991. Hal- 8-9

${ }^{5}$ Soejono Soekanto, Pengantar Penelitian Hukum, Universitas Indonesia Press, Jakarta 2007, Hal 52
} 
adalah data-data yang berkaitan dengan tugas dan wewenang Badan Kehormatan, kendala dan upaya dalam penyelesaian pelanggaran kode etik DPRD Provinsi Jambi dan Sekretariat Dewan Perwakilan Rakyat Daerah (DPRD) Provinsi Jambi yang menjadi sekretariat Badan Kehormatan DPRD Provinsi Jambi serta melakukan pengamatan lapangan sedangkan sumber hukum sekunder antara lain berupa peraturan-peraturan perundang-undangan, buku-buku, dokumen-dokumen serta tulisan-tulisan para ahli seperti makalah, artikel yang ada hubungannya dengan penelitian ini dan juga akan dilengkapi dengan data yang diperoleh dari penelitian empiris di Sekretariat DPRD Provinsi Jambi.

\section{d. Metode Pengumpulan Data.}

Pengumpulan data dimaksudkan agar diperoleh data yang berhubungan erat dengan permasalahan yang ada dalam penelitian ini. Dalam penelitian ini akan digunakan data sekunder adalah data yang bersumber atau diperoleh dari studi dokumenter atau studi kepustakaan. Studi kepustakaan dilakukan untuk memperoleh data sekunder, yaitu dengan melakukan pengkajian terhadap peraturan perundang-undangan yang berlaku, literature-literatur, dokumendokumen, karya ilmiah yang berkaitan dengan penelitian ini.

\section{e. Metode Analisis Data}

Pola analisis data dalam penelitian ini didasarkan pada metode kualitatif, yakni melalui penafsiran secara kualitatif terhadap data yang terkumpul baik data primer maupun data sekunder. Analisis kualitatif yang bersifat deskriptif analistis ini dalam kegiatan analisisnya bertitik dari analisis yuridis normatif. Hak tersebut dilakukan karena penelitian ini bertitik tolak dari peraturan perundang-undangan sebagai norma hukum positif yang menjadi dasar dalam pembentukan Badan Kehormatan DPRD dan peraturan perundang-undangan lainnya yang berkaitan dengan fungsi dan peranan Badan kehormatan DPRD selanjutnya bagaimana upaya penyelesain pelanggaran kode etik pada DPRD Provinsi Jambi.

\section{B. HASIL PENELITIAN DAN PEMBAHASAN}

\section{Deskripsi DPRD Provinsi Jambi}

a. Sejarah Perkembangan DPRD

Keberadaan DPRD sebagai lembaga penyalur aspirasi masyarakat di daerah. Semenjak berdirinya Negara Kesatuan Republik Indonesia pada tanggal 17 Agustus 1945, secara konstitusional penyelenggaraan pemerintahan daerah telah diatur eksistensinya. Hal 
ini dapat dilihat dari isi pasal 18 UUD 1945, dimana ketentuan ini menghendaki dibentuknya Undang-Undang yang mengatur tentang Pemerintahan di Daerah. Apabila dilihat dari segi hukum maupun praktek, badan legislatif daerah (DPRD) telah mengalami 8 (delapan) kali perubahan kedudukan hukum sesuai dengan pergeseran politik dan perubahan konstitusi, yang selalu dikaitkan dengan perundangundangan yang mengatur tentang pemerintahan di Daerah. Praktek ini sejalan dengan ide dasar pasal 18 UUD 1945 dan penjelasannya, yakni pembentukan Pemerintah Daerah berikut badan permusyawaratan yang mendampinginya.

Adapun pertumbuhan dan perkembangan dimaksud adalah sebagai berikut:

a. Dalam Undang-Undang Nomor 1 Tahun 1945, tentang pembentukan Komite Nasional Daerah menjadi Badan Perwakilan Rakyat Daerah, yang bersama-sama dengan dan dipimpin oleh Kepala Daerah menjalankan pekerjaan mengatur rumah tangga daerahnya, asal tidak bertentangan dengan peraturan Pemerintah Pusat dan Pemerintah Daerah yang lebih luas dari padanya.

b. Undang-Undang Nomor 22 Tahun 1948, tentang Pemerintahan Daerah. Dalam Undang-Undang ini, susunan Pemerintah Daerah terdiri dari Dewan Perwakilan Rakyat Daerah dan Dewan Pemerintah Daerah (DPD). Keadaan DPRD semakin kuat, DPRD berwenang membuat pedoman untuk DPD guna mengatur menjalankan kekuasaan, kebijaksanaan dan kewajibannya. Dengan kata lain, ruang gerak DPD ditentukan oleh DPRD, semantara itu Kepala Daerah hanya merupakan organ Pemerintah Pusat yang bertugas mengawasi pekerjaan DPRD dan DPD.

c. Undang-Undang Nomor 1 Tahun 1957, tentang Pokok-Pokok Pemerintahan Daerah. Menurut Undang-Undang ini, Pemerintah Daerah terdiri dari DPRD dan DPD, sedangkan Kepala Daerah bukan merupakan organ tersendiri dari Pemerintah Daerah, akan tetapi hanya menjadi Ketua dan anggota DPD karena jabatannya. Hak-hak dan kewajiban DPRD semakin luas, dimana DPRD mengatur dan mengurus segala urusan rumah tangga daerahnya, kecuali urusan yang oleh Undang-Undang ini diserahkan kepada pengusaha lain.

d. Penetapan Presiden Republik Indonesia Nomor 6 Tahun 1959, tentang Pemerintah Daerah. Dalam Penetapan Presiden ini, Pemerintah Daerah terdiri dari Kepala Daerah dan DPRD. Sedangkan DPD diganti dengan Badan Pemerintah Harian yang bertanggungjawab kepada Kepala Daerah. Selanjutnya disusul dengan penetapan Presiden Republik Indonesia Nomor 5 Tahun 
1960, yang mengatur tentang Dewan Perwakilan Rakyat Daerah Gotong Royong (DPRGR) dan Sekretariat Daerah.

e. Undang-Undang Nomor 18 Tahun 1965, tentang Pokok-Pokok Pemerintahan Daerah. Menurut Undang-Undang ini, DPRD merupakan unsur Pemerintah Daerah, yang tanggung jawabnya adalah membuat dan menetapkan Peraturan Daerah, mencalonkan Wakil Kepala Daerah serta mengajukan calon Kepala Daerah.

f. Undang-Undang Nomor 5 Tahun 1974, tentang Pokok-Pokok Pemerintahan di Daerah. Dalam Undang-Undang ini, yang menempatkan DPRD sebagai unsur Pemerintah Daerah, guna menjamin kerja sama dan keserasian antara Kepala Daerah dan DPRD untuk mencapai tertib pemerintahan di daerah.

g. Undang-Undang Nomor 22 Tahun 1999, tentang Pemerintah Daerah. Dalam Undang-Undang ini, DPRD dipisahkan dari Pemerintah Daerah dengan maksud untuk lebih memberdayakan DPRD dan peningkatan pertanggungjawaban Pemerintah Daerah kepada rakyat.

h. Undang-Undang Nomor 32 Tahun 2004 tentang Pemerintahan Daerah yang mengalami Amandemen Undang-undang Pemerintahan Daerah tahun 2008 dengan Undang-Undang Nomor 12 Tahun 2008. Undang-Undang 32 Tahun 2004 lahir sebagai pengganti Undang-Undang Nomor 22 Tahun 1999 yang dianggap tidak sesuai dengan perkembangan keadaan, ketatanegaraan dan tuntutan penyelenggaraan otonomi daerah, Pembagian wilayah Indonesia adalah atas darah provinsi, kabupaten dan kota. Daerah yang ada dapat mengatur dan mengurus sendiri urusan pemerintahan menurut asas otonomi dan tugas pembantuan. ${ }^{6}$ Pemerintahan provinsi dan DPRD serta pemerintahan kabupaten dan kota yang terdiri atas pemerintah daerah kabupaten, kota dan DPRD. Pemerintah daerah terdiri atas kepala daerah dan perangkat daerah. ${ }^{7}$

\section{Tugas dan Wewenang Badan Kehormatan DPRD dalam menjaga Martabat dan Kehormatan Anggota DPRD}

Agenda reformasi yang dilaksanakan secara bertahap oleh Pemerintah beberapa waktu yang lalu telah dan akan terus membuahkan banyak perubahan dalam kehidupan berbangsa dan

\footnotetext{
${ }^{6}$ Lihat Dalam Undang-Undang Nomor 32 Tahun 2004 Pasal 1 dalam Agussalim Andi Gadjong, Pemerintahan Daerah Kajian Politik dan Hukum, Ghalia Indonesia, Bogor 2007. Hal. 168

${ }^{7}$ Ibid Pasal 3.
} 
bernegara. Berbagai perubahan tersebut menyangkut segi-segi substansi pada tataran struktural dan fungsional yang diharapkan dapat membawa bangsa Indonesia bergerak menuju ke arah kehidupan yang lebih baik di segala bidang kehidupan

Timbulnya ide dan pemikiran dasar yang menumbuhkan reformasi total dalam segala aspek kehidupan bernegara dan berbangsa telah memunculkan ide yang fokus utama mewujudkan terciptanya masyarakat madani dalam proses pemerintahan, bermasyarakat, bernegara yang memiliki nilai demokrasi dan sikap keterbukaan, kejujuran, keadilan yang berorintasi pada kepentingan rakyat.

Ditinjau dari dimensi pemerintahan, bangsa Indonesia sedang memasuki masa transisi dari sistem pemerintahan yang bercorak sentralistik menuju sistem pemerintahan desentralistik dan demokratik dengan memberikan keleluasaan kepada daerah dalam mewujudkan otonomi daerah yang luas dan bertanggungjawab untuk mengatur kepentingan masyarakat menurut inisiatif dan prakarsa sendiri berdasarkan aspirasi masyarakat sesuai dengan potensi dan peraturan perundang-undangan yang berlaku serta memberikan peranan dan fungsi kepada DPRD lebih luas.

Penguatan peran DPRD dimulai dengan intensifikasi dan ekstensifikasi pelaksanaan Trifungsi Dewan Perwakilan Rakyat Daerah yakni lembaga Legislasi, lembaga Pengawasan dan lembaga Repsentasi. Implementasi ketiga fungsi itu selanjutnya dioperasionalkan dalam bentuk hak dan kewajiban anggota dalam lembaga DPRD yang kesemuanya harus diatur jelas dalam Peraturan Tata Tertib DPRD. Pelaksanaan hak dan kewajiban sebagai pengejawantahan dari fungsi tri fungsinya itu harus dapat dipertanggungjawabkan pada diri sendiri, masyarakat, lingkungan dan terutama konstituen yang telah memberikan kepercayaan penuh padanya untuk memperbaiki sistem pemerintah ke arah yang diinginkan seluruh elemen bangsa dan negara, dengan demikian baik sebagai pribadi, anggota maupun sebagai lembaga DPRD diharapkan mampu mempertanggungjawabkan setiap sikap, tutur kata dan perilakunya baik kepada publik maupun Tuhan Yang Maha Esa.

Pembentukan Badan Kehormatan adalah merupakan efek dari gagasan Reformasi Etik, Rezim Etik dan kode etik dan kode perilaku yang bersifat mengikat dan wajib ditaati oleh setiap anggota DPRD. Dasar pembentukan BK-DPRD dapat dilihat dari bagan berikut :

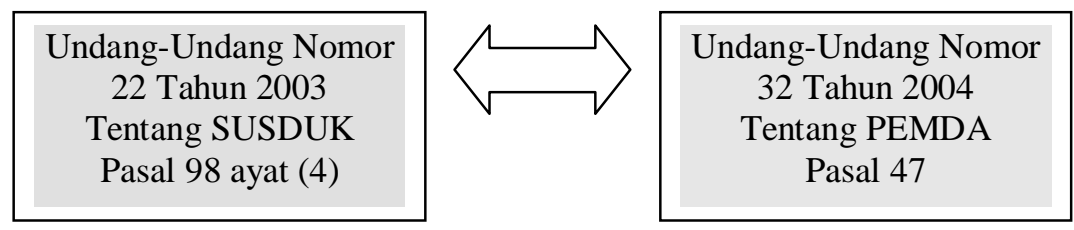



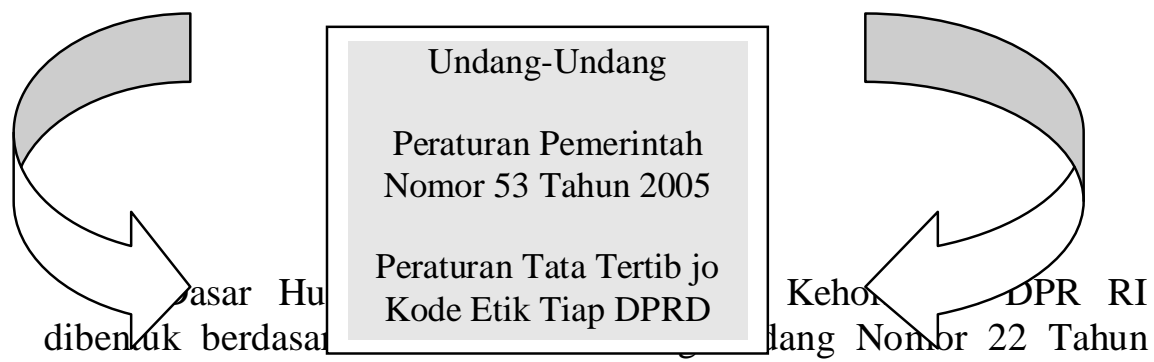

2003 tentang Susunan dan Kedudukan MPR, DPR, DPD dan DPRD harus mempunyai alat kelengkapan salah satunya adalah badan kehormatan, terbentuknya badan Kehormatan DPR-RI berdasarkan Keputusan DPR-RI Nomor. 08/ DPR RI/2005-2006 tentang Peraturan Tata Tertib DPR-RI yang ditetapkan pada tanggal 27 September 2005. sedangkan dasar hukum pembentukan Badan Kehormatan DPRD dibentuk berdasarkan Pasal 98 Undang-undang Nomor 22 Tahun 2003 tentang Susunan dan Kedudukan MPR, DPR, DPD dan DPRD harus mempunyai alat kelengkapan dan Pasal 46 ayat (1) huruf e Undang-undang Nomor 32 Tahun 2004 tentang Pemerintahan Daerah dan Pasal 47 ayat Undang-undang Nomor 32 Tahun 2004 tentang Pemerintahan Daerah dinyatakan bahwa :

(1) Badan Kehormatan DPRD dibentuk dan ditetapkan dengan Keputusan DPRD.

(2) Anggota Badan Kehormatan DPRD sebagaimana dimaksud pada ayat (1) dipilih dari dan oleh anggota DPRD dengan ketentuan.

a. untuk DPRD kabupaten/kota yang beranggotakan sampai dengan 34 (tiga puluh empat), berjumlah 3 (tiga) orang, dan untuk DPRD yang beranggotakan 35 (tiga puluh lima) sampai dengan 45 (empat puluh lima) berjumlah 5 (lima) orang.

b. Untuk DPRD provinsi yang beranggotakan sampai dengan 74 (tujuh puluh empat) berjumlah 5 (lima) orang dan untuk DPRD yang beranggotakan 75 (tujuh puluh lima) sampai dengan 100 (seratus) berjumlah 7 (tujuh) orang.

(3) Pimpinan Badan Kehormatan DPRD sebagaimana dimaksud pada ayat (2) terdiri atas seorang Ketua dan seorang Wakil Ketua yang dipilih dari dan oleh anggota Badan Kehormatan.

(4) Badan Kehormatan sebagaimana dimaksud pada ayat (1) dibantu oleh sekretariat yang secara fungsional dilaksanakan oleh Sekretariat DPRD.

Dasar hukum pembentukan badan kehormatan diatur pula pada Pada Peraturan Pemerintah Nomor 53 Tahun 2005 tentang Perubahan 
Atas Peraturan Pemerintah Nomor 25 Tahun 2004 tentang Pedoman Penyusunan Peraturan Tata Tertib Dewan Perwakilan Rakyat Daerah pada Pasal 50 yang dinyatakan bahwa:

(1) Badan Kehormatan merupakan alat kelengkapan DPRD yang bersifat tetap yang dibentuk dan ditetapkan dengan keputusan DPRD.

(2) Substansinya sama dengan Pasal 47 ayat (2) Undang-Undang Nomor 32 Tahun 2004 tentang Pemerintahan Daerah.

(3) Substansinya sama dengan Pasal 47 ayat (3) Undang-Undang Nomor 32 Tahun 2004 tentang Pemerintahan Daerah.

(4) Anggota Badan Kehormatan sebagaimana dimaksud pada ayat (1), ditetapkan dalam Rapat Paripurna DPRD berdasrkan usul dari masing-masing Fraksi.

(5) Anggota DPRD pengganti antar waktu menduduki tempat anggota Badan Kehormatan yang digantikan.

(6) Masa tugas anggota Badan Kehormatan paling lama dua setengah tahun.

(7) Badan Kehormatan sebagaimana dimaksud pada ayat (1) dibantu oleh Sekretariat yang secara fungsional dilaksankan oleh DPRD.

Sedangkan dalam Keputusan Pimpinan Dewan Perwakilan Rakyat Daerah Provinsi Jambi Nomor 6 Tahun 2006 tentang Peraturan Tata Tertib Dewan Perwakilan Rakyat Daerah Provinsi Jambi, pembentukan badan kehormatan DPRD yaitu pada pasal 54 yaitu :

1) Badan kehormatan merupakan alat kelengkapan DPRD yang bersifat tetap yang dibentuk dan ditetapkan dengan Keputusan DPRD.

2) Anggota Badan Kehormatan sebagaimana dimaksud pada ayat (1) berjumlah 5 (lima) orang.

3) Pimpinan Badan Kehormatan sebagaimana dimaksud pada ayat (1) terdiri atas seorang Ketua dan seorang wakil ketua yang dipilih dari dan oleh anggota Badan Kehormatan.

4) Sebelum Ketua dan Wakil ketua Badan Kehormatan terpilih sebagaimana dimaksud pada ayat (3), rapat dipimpin oleh anggota Badan kehormatan yang termuda usiannya sebagai pimpinan rapat sementara.

5) Anggota Badan kehormatan sebagaimana dimaksud pada ayat (1) ditetapkan dalam Rapat Paripurna DPRD berdasarkan usul dari masing-masing fraksi.

6) Apabila anngota Badan Kehormatan sebagaimana dimaksud pada ayat (5) diusulkan lebih dari 5 (lima) orang, maka harus diadakan pemilihan dengan ketentuan 1 (satu) orang anggota DPRD memiliki 5 (lima) hak suara. 
7) Anggota DPRD pengganti antar waktu menduduki tempat anggota Badan Kehormatan yang digantikan.

8) Masa Tugas Badan Kehormatan ditetapkan selama 1 (satu) tahun.

9) Badan kehormatan sebagaimana dimaksud pada ayat (1) dibantu oleh sekretariat yang secara fungsional dilaksankan oleh Sekretariat DPRD.

\section{a. Tugas Badan Kehormatan}

Adapun tugas dari alat kelengkapan dewan dalam hal ini Badan Kehormatan tercantum pada Pasal 48 Undang-undang Nomor 32 Tahun 2004 yaitu :

a. mengamati, mengevaluasi disiplin, etika dan moral para anggota DPRD dalam rangka menjaga martabat dan kehormatan sesuai dengan Kode Etik DPRD;

b. meneliti dugaan pelanggaran yang dilakukan anggota DPRD terhadap Peraturan Tata Tertib dan Kode Etik DPRD serta sumpah/janji;

c. melakukan penyelidikan, verifikasi dan klarifikasi atas pengaduan Pimpinan DPRD, masyarakat dan/atau pemilih;

d. menyampaikan kesimpulan atas hasil penyelidikan, verifikasi dan klarifikasi sebagaimana dimaksud pada huruf c sebagai rekomendasi untuk ditindaklanjuti oleh DPRD.

Tugas dan Wewenang Badan Kehormatan DPR RI tercantum dalam Keputusan Dewan Perwakilan Rakyat Republik Indonesia Nomor : 08/DPR RI/2005.2006 dalam Pasal 59.

(1). Tugas Badan Kehormatan adalah :

a. melakukan penyelidikan dan verifikasi atas pengaduan terhadap Anggota karena :

(1).Tidak dapat melaksanakan tugas secara berkelanjutan atau berhalangan tetap sebagai Anggota.

(2).Tidak lagi memenuhi syarat-syarat calon Anggota sebagaimana dimaksud dalam Undang-Undang tentang Pemilihan Umum.

(3).Melanggar sumpah/janji, Kode Etik, dan/atau tidak melaksanakan kewajiban sebagai Anggota; atau

(4).Melanggar peraturan larangan rangkap jabatan sebagaimana diatur dalam ketentuan perundangundangan.

a. menetapkan keputusan hasil penyelidikan dan verifikasi sebagaimana dimaksud pada ayat (1) huruf a. 
b. Menyampaikan keputusan sebagaimana dimaksud pada ayat (1) huruf b kepada Pimpinan DPR.

(2). Badan Kehormatan menyusun rancangan anggaran dalam rangka pelaksanaan tugasnya untuk selanjutnya disampaikan kepada BURT.

(3).Rapat-rapat Badan Kehormatan bersifat tertutup.

(4).Rapat Badan Kehormatan untuk mengambil keputusan harus memenuhi kuorum sebagaimana diatur dalam Bab XXVII.

(5). Badan Kehormatan mempunyai wewenang untuk :

a. memanggil Anggota yang bersangkutan untuk memberikan penjelasan dan pembelaan terhadap dugaan pelanggaran yang dilakukan; dan

b. memanggil pelapor, saksi, dan/atau pihak-pihak lain yang terkait untuk diminta keterangan, termasuk untuk diminta dokumen atau bukti lain.

Mengenai Tata Cara Pelaksanaan Tugas dan Wewenang Badan Kehormatan Pasal 60 yaitu : Sedangkan tugas Badan Kehormatan DPRD Provinsi Jambi berdasarkan Keputusan Pimpinan Dewan Perwakilan Rakyat Daerah Provinsi Jambi Nomor 6 Tahun 2006 tentang Peraturan Tata Tertib Dewan Perwakilan Rakyat Daerah Provinsi Jambi bahwa tugas Badan Kehormatan tercantum pada Pasal 55 yaitu :

a. mengamati, mengevaluasi disiplin, etika dan moral para anggota DPRD dalam rangka menjaga martabat dan kehormatan sesuai dengan Kode Etik DPRD;

b. meneliti dugaan pelanggaran yang dilakukan anggota DPRD terhadap Peraturan Tata Tertib dan Kode Etik DPRD serta sumpah/janji;

c. melakukan penyelidikan, verifikasi dan klarifikasi atas pengaduan Pimpinan DPRD, masyarakat dan/atau pemilih;

d. menyampaikan kesimpulan atas hasil penyelidikan, verifikasi dan klarifikasi sebagaimana dimaksud pada huruf c sebagai rekomendasi untuk ditindaklanjuti oleh DPRD.

e. Menyampaikan rekomendasi kepada Pimpinan DPRD berupa rehabilitasi nama baik apabila tidak terbukti adanya pelanggaran yang dilakukan anggota DPRD atas pengaduan Pimpinan DPRD, masyarakat dan atau pemilih.

\section{b. Wewenang Badan Kehormatan}

Untuk melaksanakan tugasnya Badan Kehormatan diberikan wewenang menurut pasal 51 A Peraturan Pemerintah Nomor 53 Tahun 2005 tentang Perubahan Atas Peraturan Pemerintah Nomor 
25 Tahun 2004 tentang Pedoman Penyusunan Peraturan Tata Tertib Dewan Perwakilan Rakyat Daerah sebagai berikut :

a. memanggil anggota yang bersangkutan untuk memberikan penjelasan dan pembelaan terhadap dugaan pelanggaran yang dilakukan; dan

b. meminta keterangan pelapor,saksi, dan atau pihak-pihak yang terkait, termasuk untuk dimintai keterangan.

Sedangkan berdasarkan Peraturan Tata Tertib DPRD Provinsi Jambi Nomor 6 Tahun 2006 bahwa untuk melaksanakan tugasnya maka Badan Kehormatan berwenang sebagai berikut :

a. memanggil anggota yang bersangkutan untuk memberikan penjelasan dan pembelaan terhadap dugaan pelanggaran yang dilakukan; dan

b. meminta keterangan pelapor,saksi, dan atau pihak-pihak yang terkait, termasuk untuk meminta dokumen atau bukti lain.

\section{Pelaksanaan Tugas dan Wewenang Badan Kehormatan Dewan Perwakilan Rakyat Republik Indonesia dan Badan Kehormatan DPRD}

\section{Pelaksanaan Tugas dan Wewenang Badan Kehormatan Dewan Perwakilan Rakyat Republik Indonesia.}

Tugas dan Wewenang Badan Kehormatan DPR RI berdasarkan Peraturan Tata Tertib Dewan Perwakilan Rakyat Republik Indonesia Nomor 08/DPR RI/I/2005.2006 Pasal 59 yaitu :

(1).Tugas Badan Kehormatan adalah :

a. melakukan penyelidikan dan verifikasi atas pengaduan terhadap Anggota:

1) Tidak dapat melaksanakan tugas secara berkelanjutan atau berhalangan tetap sebagai Anggota;

2) Tidak lagi memenuhi syarat-syarat calon Anggota sebagaimana dimaksud dalam Undang-Undang tentang Pemilihan Umum.

3) Melanggar sumpah/janji, Kode Etik, dan/atau tidak melaksanakan kewajiban sebagai Anggota; atau

4) Melanggar peraturan larangan rangkap jabatan sebagaimana diatur dalam ketentuan perundangundangan.

b. Menetapkan keputusan hasil penyelidikan dan verifikasi sebagaimana dimaksud pada ayat (1) huruf a; 
c. Menyampaikan keputusan sebagaimana dimaksud pada ayat (1) huruf b kepada Pimpinan DPR

(2) Badan Kehormatan menyusun rancangan anggaran dalam rangka pelaksanaan tugasnya untuk selanjutnya disampaikan kepada BURT.

(3) Rapat-rapat Badan Kehormatan bersifat tertutup.

(4) Rapat Badan Kehormatan untuk mengambil keputusan harus memenuhi kuorum sebagaimana diatur dalam Bab XXVII

(5) Badan Kehormatan mempunyai wewenang untuk :

a. Memanggil Anggota yang bersangkutan untuk memberikan penjelasan dan pembelaan terhadap dugaan pelanggaran yang dilakukan; dan

b. Memanggil pelapor, saksi, dan/atau pihak-pihak lain yang terkait untuk diminta keterangan, termasuk untuk diminta dokumen atau bukti lain.

Sedangkan tentang Tata cara Pelaksanaan Tugas dan Wewenang Badan Kehormatan DPR RI diatur dalam Pasal 60 Peratuan Tata Tertib Dewan Perwakilan Rakyat Republik Indonesia Nomor :08/DPR RI/I/2005.2006 yaitu :

(1) Pengaduan tentang dugaan adanya pelanggaran sebagaimana dimaksud dalam Pasal 58 ayat (1) huruf a diajukan secara tertulis oleh Pimpinan DPR, masyarakat dan/atau pemilih dilengkapi dengan identitas pengadu Badan Kehormatan.

(2) Identitas sebagaimana dimaksud pada ayat (1) harus dijamin kerahasiaannya.

(3) Badan Kehormatan menyampaikan tembusan/foto copy surat pengaduan sebagaimana dimaksud pada ayat (1) kepada Anggota yang bersangkutan selambat-lambatnya dalam waktu 14 (empat belas) hari dengan surat resmi.

(4) Badan Kehormatan menyampaikan panggilan kepada Anggota yang diadukan setelah lewat 14 (empat belas) hari sejak surat sebagimana dimaksud pada ayat (3) disampaikan.

(5) Panggilan sebagaimana dimaksud pada ayat (4) harus diterima oleh yang bersangkutan paling lambat 3 (tiga) hari sebelum sidang Badan Kehormatan yang telah ditentukan untuk itu.

(6) Dalam hal Anggota yang diadukan tidak memenuhi panggilan sebagaimana dimaksud pada ayat (5) sampai 3 (tiga) kali, Badan Kehormatan dapat segera membahas dan menetapkan keputusan tanpa kehadiran Anggota yang bersangkutan. 
(7) Anggota yang diadukan harus datang sendiri dan tidak dapat menguasakan kepada orang lain.

(8) Pengadu dan Anggota yang diadukan dapat menghadirkan saksi-saksi dalam sidang Badan Kehormatan.

(9) Dihadapan sidang Badan Kehormatan, pengadu atau Anggota yang diadukan diminta mengemukakan alasanalasan pengaduan atau pembelaan, sedangkan saksi-saksi dan/atau pihak-pihak lain yang terkait diminta keterangan, termasuk untuk diminta dokumen atau bukti lainya.

(10) Badan Kehormatan setelah melakukan penyelidikan dan/atau verifikasi terhadap pengaduan tersebut, pembelaan, bukti-bukti serta saksi-saksi, mengambil keputusan.

(11) Keputusan sebagaimana dimaksud pada ayat (10) harus memuat pertimbangan-pertimbangan yang menjadi dasarnya, dan menunjuk pasal-pasal peraturan yang dilanggar.

Ketentuan lebih lanjut mengenai tata beracara pelaksanaan tugas dan wewenang Badan Kehormatan sebagaimana dimaksud dalam Pasal 60 diatur tersendiri dengan Keputusan DPR, Tata beracara pelksanaan Tugas dan Wewenang Badan Kehormatan DPR RI dapat dibagi beberapa bagian yaitu:

\section{Tahap Pengaduan.}

a. Pengaduan tentang adanya dugaan pelanggaran diajukan secara tertulis oleh Pimpinan DPR, Masyarakat dan/atau pemilih dilengkapi dengan identitas Pengadu kepada Badan Kejormatan DPR RI, dan identitas Pengadu tersebut harus dijamin kerahasiannya oleh Badan Kehormatan DPR RI dari pihak yang tidak berkepentingan.

b. Badan Kehormatan DPR RI menyampaikan tembusan/fotocopy surat pengaduan kepada Anggota yang diadukan selambat-lambatnya dalam waktu 14 (Empat belas) hari dengat surat resmi;

c. Badan Kehormatan DPR RI menyampaikan panggilan kepada Anggota yang diadukan setelah lewat 14 (empat belas) hari sejak surat sebagaimana dimaksud pada ayat (3) disampaikan;

\section{Tahap Pemanggilan.}

a. Panggilan atau surat pemanggilan dari Badan Kehormatan DPR RI harus diterima oleh Anggota yang diadukan paling lambat 3 (tiga) hari sebelum sidang Badan Kehormatan DPR RI yang telah ditentukan untuk itu; 
b. Apabila Anggota yang diadukan tidak memenuhi panggilan Badan Kehormatan sampai 3 (tiga) kali, Badan Kehormatan dapat segera membahas dan menetapkan keputusan tanpa kehadiran Anggota yang bersangkutan.

\section{Tahap Persidangan}

a. Anggota yang diadukan harus datang sendiri dan tidak dapat menguasakan kepada orang lain;

b. Pengadu dan Anggota yang diadukan dapat menghadirkan saksi-saksi dalam sidang Badan Kehormatan;

c. Dihadapan sidang Badan Kehormatan, Pengadu atau Anggota yang diadukan diminta menemukakan alasan-alasan pengaduan atau pembelaan, sedangkan saksi-saksi dan atau pihak-pihak lain yang terkait diminta keterangan, termasuk untuk diminta dokumen atau bukti lainnya.

\section{Tahap Pegambilan Keputusan}

a. Badan Kehormatan setelah melakukan penyelidikan dan atau verifikasi terhadap pengaduan tersebut, pembelaan, buktibukti serta saksi-saksi, mengambil Keputusan;

b. Keputusan harus memuat pertimbangan-pertimbangan yang menjadi dasarnya dan menunjukan pasal-pasal peraturan yang dilanggar.

Pengambilan Keputusan atau putusan Badan Kehormatan DPR RI dapat dibagi menjadi :

1. Putusan Badan Kehormatan DPR-RI bersifat Final dan mengikat.

2. Putusan BK DPRD bersifat rekomendasi/kesimpulan. Sedangkan Pemberian Sanksi Badan Kehormatan DPR-RI diatur menurut Peraturan Tata Tertib diatur dalam Pasal 62 yaitu :

(1) Setelah Badan Kehormatan melakukan penelitian dan mempertimbangkan pengaduan, pembelaan, bukti-bukti serta saksi-saksi, badan kehormatan dapat memutuskan sanksi berupa :

a.Teguran tertulis;

b.Pemberhentian dari jabatan Pimpinan DPR atau Pimpinan alat kelengkapan DPR; atau c.Pemberhentian sebagai Anggota.

(2) Sanksi berupa teguran tertulis, sebagaimana dimaksud pada ayat (1) huruf a, disampaikan oleh Pimpinan DPR kepada Anggota yang bersangkutan. 
(3) Sanksi yang diberikan sebagaimana dimaksud pada ayat (1) huruf $\mathrm{b}$ dan huruf c disampaikan kepada Pimpinan DPR untuk dibacakan Rapat Paripurna.

(4) Pemberhentian sebagai Anggota sebagaimana dimaksud pada ayat (1) huruf c, oleh Pimpinan DPR disampaikan kepada Presiden untuk diresmikan.

(5) Keputusan Presiden sebagaimana dimaksud pada ayat (4), disampaikan oleh Pimpinan DPR kepada Anggota yang bersangkutan.

Tahap Rehabilitasi diatur pada Pasal 63 Peraturan Tata Tertib DPR RI yaitu terdiri dari :

(1) Badan Kehormatan dapat menetapkan keputusan rehabilitasi, apabila Anggota yang diadukan tidak melanggar peraturan perundang-undangan dan Kode Etik.

(2) Rehabilitasi sebagaimana dimaksud pada ayat (1), diumumkan dalam Rapat Paripurna dan dibagikan kepada seluruh Anggota,

\section{Pelaksanaan Tugas dan Wewenang Badan Kehormatan DPRD}

BK dalam pelaksanaan Tugas dan wewenangnya tetap mengacu Undang-undang Nomor 32 Tahun 2004 dan dan Peraturan Pemrintah Nomor 53 Tahun 2005 tentang Perubahan atas Peraturan Pemerintah Nomor 25 Tahun 2004 tentang Pedoman Penyusunan Peraturan Tata Tertib Dewan Perwakilan Rakyat Daerah, di DPRD Provinsi Jambi Pelaksanaan Tugas dan Wewenang diatur dalam Keputusan Pimpinan Dewan Perwakilan Rakyat Daerah Provinsi Jambi Nomor 6 Tahun 2006 tentang Peraturan Tata Tertib Dewan Perwakilan Rakyat Daerah Provinsi Jambi yaitu dalam Pasal 57 dan Pasal 58 :

\section{Pasal 57}

(1). Mekanisme pengaduan/pelaporan pelanggaran :

a. pengaduan/pelaporan tentang dugaan adanya pelanggaran diajukan secara tertulis kepada Pimpinan DPRD disertai identitas pelapor yang jelas dengan tembusan Badan Kehormatan;

b. pengaduan/pelaporan sebagaimana dimaksud pada huruf a, dikesampingkan apabila tidak disertai dengan identitas pelapor yang jelas; 
c. pimpinan DPRD menyampaikan pengaduan /pelaporan kepada Badan Kehormatn untuk ditindak lanjuti;

d. Apabila dalam waktu 7 (tujuh) hari sejak diterimanya pengaduan/pelaporan sebagaimana dimaksud pada huruf a tidak disampaikan oleh Pimpinan DPRD, Badan Kehormatan dapat menindak lanjuti.

(2). Mekanisme penelitian dan pemeriksaan pengaduan /laporan:

a. Badan Kehormatan melakukan penelitian dan pemeriksaan pengaduan/laporan melalui permintaan keterangan dan penjelasan pelapor, saksi dan atau yang bersangkutan serta pemeriksaan dokumen atau bukti lain.

b. Badan kehormatan membuat kesimpulan hasil penelitian dan pemeriksaan dengan disertai berita acara penelitian dan pemeriksaan.

c. Badan kehoramatan menyampaikan kesimpulan hasil penelitian dan pemeriksaan kepada Pimpinan DPRD untuk ditindak lanjuti dalam Rapat Paripurna DPRD.

d. Rapat Paripurna DPRD dilaksanakan selambatlambatnya 7 (tujuh) hari setelah kesimpulan sebagaimana huruf b diterima oleh pimpinan DPRD.

e. Rapat Paripurna DPRD dapat menyetujui atau menolak kesimpulan Badan Kehormatan.

f. Apabila Rapat Paripurna DPRD menolak kesimpulan Badan Kehormatan dan menyatakan yang bersangkutan tidak bersalah, DPRD berkewajiban merehabilitasi nama baik yang bersangkutan secara tertulis dan disampaikan kepada yang bersangkutan, Pimpinan Fraksi dan Pimpinan Partai Politik yang bersangkutan.

\section{Pasal 58}

1) DPRD menetapkan sanksi atau rehabilitasi terhadap anggota yang dilaporkan setelah mendengar pertimbangan dan penilaian dari Badan Kehormatan.

2) Sanksi yang diberikan dapat berupa teguran lisan atau teguran tertulis sampai dengan diberhentikan sebagai anggota sesuai ketentuan peraturan perundangundangan.

3) Sanksi berupa teguran lisan dan teguran tertulis disampaikan oleh Pimpinan DPRD kepada anggota yang bersangkutan dan disampaikan kepada Pimpinan Fraksi 
dan Pimpinan Partai politik yang bersangkutan secara tertulis.

4) Sanksi berupa pemberhentian sebagai anggota DPRD, diproses sesuai dengan ketentuan peraturan perundangundangan.

\section{Kendala dan upaya Badan Kehormatan DPRD dalam penyelesaian Pelanggaran Kode Etik pada DPRD Provinsi Jambi.}

Praktek dan kinerja dalam pelaksanaan tugas dan wewenang Badan Kehormatan tidak hanya dengan norma-normanya yang kurang memperhitungkan real politic. Kritik yang dilancarkan terhadap kinerja Badan Kehormatan adalah sulitnya memisahkan politik dan moral. Karena, pemahaman publik tentang politik masih belum didasari atas refleksi pelaksanaan Kode Etik, sehingga seakan-akan etika politik menjadi kurang relevan. Relevansi etika politik terletak pada kemampuannya untuk mengelola kekuatan itu dan mengatur kepentingan-kepentingan kelompok dengan membangun institusiinstitusi politik yang lebih adil. Dalam hal ini, seorang anggota Badan Kehormatan idealnya menguasai Filsafat Politik, Filsafat Hukum dan Ilmu Hukum sebagai bentuk refleksi mendalam yang memungkinkan kehidupan politik mengungkap struktur-struktur, makna, dan nilainya secara etis.

Sistem pengawasan berbasis etika yang dijalankan oleh Badan Kehormatan merupakan hal yang baru dalam struktur politik di Indonesia. Dalam sistem demokrasi, sistem pengawasan berbasis etika ini akan bersikap kritis terhadap manipulasi gagasan, nilai, dan opini yang membuat sulit dibedakannya antara isu dengan fakta. Secara konsisten, Badan Kehormatan berupaya untuk melaksanakan sistem pengawasan berbasis etika dengan berpegang setidaknya pada 3 (tiga) hal, yaitu:

a. Badan Kehormatan berusaha mengambil jarak dan kritis terhadap realitas politik;

b. Badan Kehormatan senantiasa bekerja untuk melakukan pengujian terhadap nilai-nilai, termasuk nilai-nilai moral dalam Kode Etik; dan

c. Badan Kehormatan tetap berada dalam suatu perspektif tentang tujuan Kode Etik diterapkan di parlemen.

Dengan demikian, anggota partai politik yang telah dipilih melalui mekanisme Pemilihan Umum dan masuk menjadi anggota parlemen 
dapat tunduk serta bertindak kolektif berdasarkan Kode Etik dan Peraturan Tata Tertib. Kode etik merupakan perangkat aturan penting dalam menjamin akuntabilitas seorang anggota Parlemen. Kode etik merupakan alat untuk menjamin proses kinerja seorang anggota sudah mencapai standar etika politik yang sehat, yang bebas dari campur aduk kepentingan pribadi, sikap tidak disiplin, korupsi dan kolusi, dan penegasian terhadap peraturan yang berlaku."

Di sisi lain, "Apakah Kode Etik merupakan alat untuk menjamin proses kinerja seorang Anggota parlemen guna mencapai standar etika politik yang sehat?" Ini merupakan pertanyaan etis yang mempunyai relevansi sosial-politik, mengikuti Teori Etika Deontologi (wajib tidaknya perbuatan atau keputusan kita) atau Teori Etika Utilitarisme (berorientasi menyenangkan sebagian besar orang). Tantangan untuk menciptakan aturan Kode Etik yang berfungsi sebagai alat penjamin kinerja, dapat dilihat secara umum sebagai problema yang senantiasa dihadapi oleh Badan Kehormatan Yaitu :

1. Problema pertama adalah terkait dengan kinerja Badan Kehormatan dengan suatu misteri keilmuan "Etika dan Hukum" yang belum terbuka. "Badan Kehormatan bergerak dalam wilayah Etika atau wilayah Hukum?" Pendapat semacam ini seringkali dijumpai baik di dalam Dialog, Rapat, maupun Sidang Badan Kehormatan, bahkan senantiasa on going debate di kalangan Anggota Badan Kehormatan. Perdebatan produktif tentang "Etika atau Hukum" berjalan dengan melihat sejumlah ketentuan "perilaku etis" dalam Kode Etik yang berkaitan dengan hukum positif. Misalnya, perilaku menerima imbalan atau hadiah dari mitra kerja yang diatur dalam Kode Etik mempunyai hubungan normatif dengan hukum positif yang mengatur tentang gratifikasi. Sejauh mana Badan Kehormatan akan memproses pengaduan dugaan penerimaan imbalan atau hadiah dari mitra kerja, bila dalam ketentuan Kode Etik itu sendiri juga merujuk kepada hukum pidana mengenai gratifikasi? "Apakah Badan Kehormatan berwenang memutus perkara tentang perilaku menerima imbalan atau hadiah dari mitra kerja, sekaligus perihal gratifikasi?" Tantangan yang terbuka adalah di manakah batasan antara perkara Etik(a) dan perkara Hukum (Positif) itu sebenarnya? Pertanyaan kritis dari dalam Badan Kehormatan sendiri mengisyaratkan adanya problem epistemologis antara status keilmuan Etika dan Ilmu Hukum, dengan batasan kinerja Badan Kehormatan itu sendiri. Untuk sementara, dalam menjawab pertanyaan kritis itu maka diajukan suatu pendekatan yang praktis, teknis, dan

\footnotetext{
${ }^{8}$ Anom Surya Putra, Op. Cit Hal 2-4
} 
proseduralis dalam sistem hukum Amerika Serikat. Melalui penelitian legislatif yang dilakukan National Democratic Institute for International Affairs, dalam sub tema "Hukum Pidana versus Peraturan Etik," terdapat temuan fakta bahwa:

2. Problema kedua adalah persoalan lanjutan dari persoalan "Etika atau Hukum" pada problema pertama, yaitu kinerja Badan Kehormatan dalam pengambilan keputusan yang bentuk formalnya terwujud dalam bentuk sanksi. Hakikatnya, pengambilan keputusan etik apapun oleh Badan Kehormatan disertai dengan unsur kebebasan. Dalam praktek pengambilan keputusan berupa sanksi, Anggota Badan Kehormatan senantiasa dihimbau oleh nuraninya sendiri untuk tidak berpihak atau tidak terikat pada kepentingan Fraksi baik kepentingan ideologis, pragmatis, maupun praktis. Bersamaan dengan praktek pengambilan keputusan itu, Anggota Badan Kehormatan terlihat harus memanfaatkan seluruh akal budi, kemampuan, dan keahliannya secara bebas dengan suatu rasa tanggung jawab yang luas. Mengapa hal ini dikatakan "harus"? Ketentuan dalam Kode Etik hanya mengatur perilaku dan ucapan tertentu tanpa mempunyai korelasi (hubungan yang kuat). dengan sanksi. Misalnya, terdapat Anggota yang terlibat dalam perilaku dan ucapan yang diskriminatif terhadap suku tertentu di Indonesia. Dalam Kode Etik tidak diatur bahwa perbuatan tersebut merupakan perilaku yang melanggar kewajiban dan dapat dijatuhi sanksi Teguran Tertulis. Akibatnya, Anggota Badan Kehormatan harus bekerja keras untuk menafsirkan seluruh ketentuan dalam Kode Etik berdasarkan data-data yang terungkap dalam penyelidikan, verifikasi, dan Sidang Badan Kehormatan. Seandainya nilai-nilai yang dianut oleh masing-masing Anggota Badan Kehormatan itu tidaklah sama mengenai apa makna kewajiban dan diskriminasi itu, niscaya penjatuhan sanksi merupakan problem psikologis dan sosial atau suatu aksi politik. Hal ini berarti membuat Anggota Badan Kehormatan tidak memiliki kebebasan dalam menjatuhkan sanksi sebagaimana peneliti pahami dalam sisi pandang Etika sebagai ilmu pengetahuan. Padahal, unsur kebebasan dalam praktek pengambilan keputusan etik lebih penting daripada sekedar unsur keharusan melalui penjatuhan sanksi.

Pendapat Immanuel Kant yang sebagian besar diapresiasi oleh Filsafat Hukum yaitu tentang kewajiban, selayaknya dihayati sebagai suatu keharusan tanpa syarat. Hal ini lazim disebut Imperatif Kategoris sebagai dasar kehidupan moral manusia. Dalam konteks Imperatif Kategoris, Anggota Badan Kehormatan 
menjatuhkan sanksi bukanlah untuk mencapai tujuan tertentu (popularitas, misalnya), melainkan sebagai bentuk penghayatan bahwa penjatuhan sanksi itu (juga) baik pada dirinya sendiri sebagai Anggota Badan Kehormatan. Dengan demikian, dalam pengambilan keputusan tersebut, Anggota Badan Kehormatan bebas dalam melakukan penghayatan tentang norma-norma kewajiban dalam Kode Etik.

Berbeda halnya dengan adanya unsur keharusan dalam membuat sanksi terhadap Anggota yang dicontohkan di atas, maka seolah terdapat rumus: "Jika menjatuhkan sanksi X, maka Saya harus melakukan Y". Hal ini lazim disebut Imperatif Hipotesis Problematis. Imperatif ini bukanlah imperatif moral. Dalam contoh di atas, maka tindakan pemberian sanksi digunakan sebagai sarana untuk tujuan tertentu (popularitas, misalnya), dengan syarat-syarat tertentu pula seperti mencari pasal-pasal dalam Kode Etik agar bisa menghukum Anggota parlemen seberat-beratnya. Hal ini kuranglah etis bila dipandang dari sisi pendapat Etika Immanuel Kant. Namun demikian, pendekatan Etika Immanuel Kant sebagaimana sedikit diuraikan di atas belumlah cukup untuk menjernihkan problema rasionalitas pengambilan keputusan terhadap perkara etik.

3. Problema Ketiga adalah kinerja Badan Kehormatan terkait dengan tata aturan Etika Legislatif yang lebih ketat, seperti Kode Perilaku (code of conduct). Kebutuhan untuk memperbaharui rumusan Kode Etik (code of ethics) merupakan "kebutuhan jangka pendek yang tak-terelakkan", sedangkan keinginan untuk menyusun Kode Perilaku (code of conduct) adalah "keinginan jangka panjang yang tak dapat diabaikan".

\section{III . Kesimpulan}

Berdasarkan hasil penelitian, baik penelitian kepustakaan maupun penelitian lapangan, secara analisis dan pembahasan yang telah penulis lakukan pada bab-bab terdahulu, berikut disajikan kesimpulan yang merupakan jawaban terhadap permasalahan dalam penelitian sebagai berikut :

\section{Tugas dan Wewenang Badan Kehormatan dalam Menjaga Martabat dan Kehormatan Anggota DPRD.}

Badan Kehormatan adalah merupakan lembaga baru di parlemen di Indonesia, awalnya Badan Kehormatan di DPR dan DPRD pada periode sebelumnya diberi nama "Dewan Kehormatan" yang tidak bersifat tetap dan hanya dibentuk bila terdapat kasus dan disepakati 
untuk menuntaskan suatu kasus yang menimpa anggota DPR dan DPRD. Tepat pada Periode 2004-2009, Badan Kehormatan di Indonesia didisain sebagai alat kelengkapan yang bersifat tetap, artinya Badan Kehormatan merupakan suatu keharusan untuk segera dibentuk di seluruh parlemen di Indonesia, Argumentasi ini didapatkan bila kita menafsirkan Undang-Undang Nomor 22 Tahun 2003 tentang Susunan dan Kedudukan MPR, DPR, DPD dan DPRD jo. Undang-Undang Nomor 32 Tahun 2004 tentang Pemerintahan Daerah. DPRD sendiri adalah merupakan Lembaga legislatif yang para anggotanya terpilih melalui mekanisme Pemilihan Umum, sebagai sebuah Institusi, keberadaan sangat penting dan strategis dalam melaksanakan perannya guna mewujudkan pemerintahan yang baik dan bersih (good and clean governance) dalam menjalankan fungsinya perlu senantiasa mengedepankan komitmen moral dan profesionalitas. Badan Kehormatan sebagai salah satu alat kelengkapan DPRD baru beberapa tahun belakangan ini muncul ke permukaan dan diberitakan media massa, khususnya setelah era Reformasi bergulir. Karena lembaga ini menyangkut masalah kehormatan para wakil rakyat di DPRD, Belakangan ini berbagai pelanggaran kode etik oleh anggota DPR RI maupun anggota DPRD semakin banyak terungkap, mulai dari percaloan, pemerasan, penyalahgunaan kewenangan, sampai permesuman. Untuk menyikapi ini, kewenangan BK DPR dan khususnya BK DPRD perlu diperbesar. Badan Kehormatan DPR RI dan BK DPRD perlu mengubah mekanisme yang selama ini dilakukan dalam menanggapi dugaan penyimpangan etika anggota DPR maupun DPRD dengan tidak lagi bersifat pasif, tetapi bersifat proaktif, Pembentukan Badan Kehormatan adalah merupakan efek dari gagasan Reformasi Etik, Rezim Etik dan kode etik dan kode perilaku yang bersifat mengikat dan wajib ditaati oleh setiap anggota DPRD. pelaksanaan Tugas dan wewenang Badan Kehormatan tetap mengacu pada Undang-undang Nomor 32 Tahun 2004 tentang Pemerintahan Daerah yang dalam pelaksanaannya wajib menetapkan Peraturan Tata Tertib dalam rangka pembentukan, susunan, tugas dan wewenang serta memperjelas pelaksanaan tugas dan mekanisme kerja anggota DPRD dan Peraturan Pemerintah Nomor 53 Tahun 2005 tentang Perubahan atas Peraturan Pemerintah Nomor 25 Tahun 2004 tentang Pedoman Penyusunan Peraturan Tata Tertib Dewan Perwakilan Rakyat Daerah, di DPRD Provinsi Jambi Pelaksanaan Tugas dan Wewenang diatur dalam Keputusan Pimpinan Dewan Perwakilan Rakyat Daerah Provinsi Jambi Nomor 6 Tahun 2006 tentang Peraturan Tata Tertib Dewan Perwakilan Rakyat Daerah Provinsi 
Jambi. DPRD wajib menyusun kode etik hal ini tercantum pada Undang- Undang-undang Nomor 32 Tahun 2004 tentang Pemerintahan Daerah DPRD dan Undang-undang Nomor 22 Tahun 2003 tentang Susunan dan Kedudukan MPR, DPR, DPD, dan DPRD.pada untuk menjaga martabat dan kehormatan anggota DPRD dalam menjalankan tugas dan wewenangnya. melayani fungsi internal dan juga eksternal. Fungsi internal untuk meningkatkan standar etik dan kinerja pejabat publik, dan fungsi eksternal untuk mendapatkan kembali kepercayaan publik/rakyat.

\section{Kendala dan upaya Badan Kehormatan DPRD dalam penyelesaian Pelanggaran Kode Etik pada DPRD Provinsi Jambi.}

Praktek dan kinerja dalam pelaksanaan tugas dan wewenang Badan Kehormatan tidak hanya dengan norma-normanya yang kurang memperhitungkan real politic. Kritik yang dilancarkan terhadap kinerja Badan Kehormatan adalah sulitnya memisahkan politik dan moral. Karena, pemahaman publik tentang politik masih belum didasari atas refleksi pelaksanaan Kode Etik, sehingga seakan-akan etika politik menjadi kurang relevan. Relevansi etika politik terletak pada kemampuannya untuk mengelola kekuatan itu dan mengatur kepentingan-kepentingan kelompok dengan membangun institusi-institusi politik yang lebih adil. Kendala dalam pelaksanaan tugas dan wewenang Badan kehormatan DPRD disebabkan oleh :

1. Hambatan External yaitu peraturan Perundang-undangan.

Salah satu contoh terlihat dari kelemahan tekhnik penelitian pada Pasal 51 B Peraturan Pemerintah Nomor 53 Tahun 2005 yang menyatakan bahwa pemeriksaan dokumen hanya dicukupkan pada bukti formil berupa dugaan tertulis dan identitas pelapor dan juga badan kehormatan melakukan penelitian dan pemeriksaan pengaduan/laporan melalui permintaan keterangan dan penjelasan pelapor saksi dan atau yang bersangkutan serta pemeriksaan dokumen atau bukti lain. Hal ini terlihat bias menimbulkan penafsiran yang berbeda, putusan atau kesimpulan atau rekomendasi etik dari Badan Kehormatan DPRD merupakan keputusan etik dan bukan keputusan politik sehingga tidak perlu ditolak atau diterima dalam Rapat Paripurna DPRD.

2. Hambatan Internal. hal ini tercermin dari kelemahan para anggota Badan Kehormatan yang juga berasal dari internal DPRD yang tentu saja memiliki kecenderungan subjektif dalam penyelenggaraan tugas dan kewenangannya. 


\section{b. Saran}

1. Perlu adanya peningkatan pengetahuan bagi seorang anggota Badan Kehormatan idealnya menguasai Filsafat Politik, Filsafat Hukum dan Ilmu Hukum sebagai bentuk refleksi mendalam yang memungkinkan kehidupan politik mengungkap struktur-struktur, makna, dan nilainya secara etis.

2. Badan Kehormatan hendaknya melibatkan pihak-pihak lain diluar anggota Badan Kehormatan DPRD sendiri sehingga mekanisme pengawasan yang berbasis etika dapat terwujud lebih independen dan objektif. Sehingga Badan kehormatan mampu berperan tidak hanya sekadar menjadi lembaga penjaga moral dan integritas anggota DPR dan DPRD melainkan juga menjadi mekanisme internal untuk menegakkan kode etik.

\section{Daftar Pustaka}

Abdul Kadir Muhammad. Etika Profesi Hukum. Citra Aditya Bhakti. Bandung. 1997.

Abdul Azis Thaba, Islam dan Negara dalam Politik Orde Baru, Jakarta. Gema Insani Press, 1996

Abdul Mukthie Fadjar, Hukum Konstitusi dan Mahkamah Konstitusi, Kerjasama Konstitusi Press Jakarta dan Citra Media Yokyakarta. 2006.

Agussalim Andi Gadjong, Pemerintahan Daerah Kajian Politik dan Hukum, Ghalia Indonesia, Bogor 2007.

Anom Surya Putra, Naskah Kode Etik DPR RI dan Tata Beracara, Bahan Project Management Unit PROPER UNDP Bekerjasama dengan Sekretariat Jenderal DPR RI 2007. 
, Mekanisme Kerja Badan Kehormatan, Makalah disampaikan untuk pelatihan Badan Kehormatan oleh LSPPAD, Hotel Mercure Jakarta , 22 April 2006.

Arbi Sanit, Perwakilan Politik Indonesia, Rajawali, Jakarta, 1985

Bambang Waluyo, Penelitian Hukum Dalam Praktek. Jakarta : Sinar Grafika, 1991

Bahan Sosialisasi Badan Kehormatan DPR RI- DPRD, di DPRD Provinsi Jambi tanggal 18 Februari 2008.

Cornelis Lay, Tantangan Domestik dan Internasional DPRD. Catatan Pengantar "Orientasi Anggota DPRD Se-Eks Karesidenan Banyumas” Baturaden 19-22 Januari 2000.

Dahlan Thaib, Implementasi Sistem Ketatanegaraan Menurut UUD 1945. Liberty. Yokyakarta 1998.

Departemen Pendidikan dan Kebudayaan RI, Kamus Bahasa Indonesia, Balai Pustaka, Jakarta 1995.

Dati Fatimah dan Mail Sukribo, DPR Uncensored, Mizan Media Utama, Bandung. 2008

, Sejarah kebangkitan Nasional Daerah Jambi, Jakarta: Pusat Penelitian Sejarah dan Budaya Depdikbud, 1978.

http://badankehormatan.wordpress.com/category/badan-kehormatandprd/, diakses pada tanggal 24 Desember 2008.

H. De Vos, Pengantar Etika, terjemahan Soejono Soemargono, Tiara Wacana Yogya. Yokyakarta, 1987. 
H. Gerge Frederickson \& David K.Hart. "The Public Service and the Patriotism of Benevolence", Public Administration Review. September/ Oktober, 1985

Haris Jumadi, Saya Pegawai Rakyat Memaknai Profesi sebagai Anggota Dewan, Harakatuna Publishing, Bandung. 2006

E. Sumaryono, Etika Profesi Hukum, Relevansi Teori Hukum Kodrat Thomas Aquinas. Kanisus, Yogyakrta, 1995

Firman Hariyanto, terjemahan Nizham Al-Islam, Al-Mulk wa AdDaulah karangan Muhammad Al-Mubarak, Pustaka Pelajar, Yokyakarta. 2000.

Frans-Magnis-Suseno, Etika Dasar: Masalah-masalah Pokok Filsafat Moral, Cet. 3. Kanisus. Yokyakarta. 1991.

Haryatmoko, Etika Politik dan Kekuasaan, Pt Kompas Media Nusantara. Jakarta, 2003.

Hendrikus Triwibawanto Dedeona " Akuntabilitas Kelembagaan Eksekutif”. Jurnal Ilmu Administrasi, STIA LAN, Bandung Vol. 4 Nomor 1 Maret 2007,

Ichlasul Amal, Pemberdayaan DPR dalam Upaya Demokratis, Pidato Pengukuhan Guru Besar Universitas Gadjah Mada, Yokyakarta, Tahun 1995 dalam Siswanto Sunarno, Hukum Pemerintahan Daerah di Indonesia. Sinar Grafika, Jakarta. 2008

Ismail Sunny. Pembagian Kekuasaan Negara, Aksara Baru. Jakarta. 1986. 
I.R. Podejawijatna, Etika: Filsafat Tingkah Laku,Rineka Cipta, 1990 Jakarta

Jimly Ashiddiqie. Format Kelembagaan Negara dan Pergeseran Kekuasaan Dalam UUD 1945, FH UII Press. Yokyakarta.

Kevin Raymond Evans, Sejarah Pemilu dan Partai Politik di Indonesia, Jakarta: PT. Arise Consultancies, 2003.

Lili Rasjidi, Dasar-dasar Filsafat Hukum, Rajawali Press, Jakarta 1988.

Lorens Bagus, Kamus Filsafat. Gramedia Pustaka Utama, Jakarta.1996

Makmur Amir dan Reni Dwi Purnomowati, Lembaga Perwakilan Rakyat, Pusat Studi Hukum Tata Negara Universitas Indonesia. Jakarta. 2005

Markus Gunawan, 2008. Buku Pintar Calon Anggota dan Anggota Legislatif (DPR, DPRD, DPD), Visimedia Pustaka, Jakarta

Miriam Budiardjo, Dasar-dasar Ilmu Politik, Gramedia Pustaka Utama, Jakarta 1992.

Mochtar Mas'oed, Ekonomi dan Struktur Politik Orde Baru 19661971, Jakarta: LP3ES,1989.

Aneka Pemikiran Tentang Kuasa dan Wibawa, Sinar Harapan, Jakarta, 1991

M. Oosterhagen, Separation of Power as a Form of Control and the Dutch Constitution, dalam Carla M. Zoethout, et al (Eds) Conrol In Constutional Law, Martinus Nijhoff Publishers, Dordrecht/Boston/London. 1993 
Moh. Mahfud MD, Hukum dan Pilar-Pilar Demokrasi, Gama Media, Yokyakarta, 1999.

Mochamad Isnaeni Ramadhan, Peran BK-DPRD dalam Penegakan Etika, makalah disampaikan pada Legislatif Confernce International Network for Regional Development, Jakarta tanggal 8-9 September 2006.

M. J. Manulang, Dasar-dasar Manajemen, Gramedia, Jakarta, 1981.

Ni'matul Huda, Otonomi Daerah Filosofi sejarah dan Perkembangan dan Problematika, Pustaka Pelajar, Yokyakarta. 2005.

Nino Carlos Santiago, The Constitution of Deliberative Democracy, YALE University Press. London dalam Abdul Mukthie Fadjar, Hukum Konstitusi dan Mahkamah Konstitusi, Kerjasama Konstitusi Press Jakarta dan Citra Media Yokyakarta. 2006.

Nawawi Hadari, Metodologi Penelitian Bidang sosial, Bumi Aksara, Jakarta 1993.

O.P. Simorangkir, Etika Jabatan, AP Press, 1978

Rozali Abdullah, Pelaksanaan Otonomi Luas dan Isu Federalisme Sebagai Alternatif, PT. Raja Grafindo Persada, Jakarta, 2006.

Satjipto Raharjo. Ilmu Hukum. Citra Aditya Bhakti, Bandung. 2000.

Sayuti Una, Pergeseran Kekuasaan Pemerintahan Daerah Menurut Konstitusi Indonesia (Kajian tentang Distribusi Kekuasaan antara DPRD dan Kepala Daerah Pasca kembali berlakunya UUD 1945) UII Press, Yokyakarta. 2004 
Shidarta, Moralitas Profesi Hukum Suatu Tawaran Kerangka Berfikir, PT. Refrika Aditama, Bandung. 2006.

Siswanto Sunarno, Hukum Pemerintahan Daerah, Sinar Grafika Makasar. 2005.

Sedarmayanti, Good Governance (Kepemerintahan Yang Baik) Dalam Rangka Otonomi Daerah, Mandar Maju, Bandung, 2003

Good Governance (Kepemerintahan Yang Baik) bagian kedua Membangun Sistem Manajemen Kinerja Guna Meningkatkan Produktivitas Menuju Good Governance (kepemerintahan yang Baik). Penerbit Mandar Maju. Bandung. 2004.

Soehino. Hukun Tata Negara: Negara Kesatuan Republik Indonesia Berdasarkan Pancasila dan Undang-Undang Dasar 1945, Liberty. Yokyakarta.1985.

Soejono Soekanto dan Sri Mamuji, Penelitian Hukum Normatif, Suatu Tinjauan singkat, Cetakan Ke II. Jakarta. Rajawali 1998.

Pengantar Penelitian Hukum, Universitas Indonesia Press, Jakarta. 2007.

Sumali. Reduksi Kekuasaan Eksekutif di bidang Peraturan Pengganti Undang-Undang (Perpu). UMM, Malang.

Sujamto, Aspek-aspek Pengawasan di Indonesia, Sinar Grafika, Jakarta. 1990.

Sudono syueb, Paradoks Politik. PT. Java Pustaka Media Utama, Surabaya, 2005 
Terry, George R dan Ruc Leslie W, Dasar-dasar Manajemen, Buku Aksara. Jakarta 1986.

Viktor M. Situmorang dan Jusuf Juhir, Aspek Hukum Pengawasan melekat Dalam Lingkungan Aparatur Pemerintah, Rineka Cipta, Jakarta (Cetakan II), 1998

WahYudi Kumorotomo, Etika Administrasi Negara, Pt. Raja Grafindo Persada, Jakarta. 2008

Wiliam Liddle, Partisipasi dan Partai Politik: Indonesia pada Masa Awal Orde Baru, Jakarta: Grafiti Press, 1992.

W.J.S Perwadarminta, Kamus Bahasa Indonesia, Balai Pustaka, 1976

Yan Pramdya Puspa, Kamus Hukum, Aneka Ilmu Semarang 1977

\section{PERATURAN PERUNDANG-UNDANGAN}

Republik Indonesia, Undang-undang Nomor 22 Tahun 2003 Tentang Susunan Kedudukan Majelis Permusyawaratan Rakyat, Dewan Perwakilan Rakyat, Dewan Perwakilan Daerah dan Dewan Perwakilan Rakyat Daerah (Lembaran Negara Republik Indonesia Tahun 2003 Nomor 92)

Republik Indonesia, Undang-undang Nomor 32 Tahun 2003 Tentang Pemerintahan Daerah dan Penjelasan (Lembaran Negara Republik Indonesia Tahun 2004 Nomor 125)

Peraturan Pemerintah Nomor 53 Tahun 2005 tentang Perubahan Atas Peraturan Pemerintah Nomor 25 Tahun 2004 tentang pedoman Penyusunan Peraturan 
Tata Tertib Dewan Perwakilan Rakyat Daerah (Lembaran Negara Republik Indonesia Tahun 2005 Nomor 130 Tambahan Lembaran Negara Republik Indonesia Nomor 4569.

Keputusan Dewan Perwakilan Rakyat Republik Indonesia Nomor.08/DPR RI/i/2005-2006 tentang Peraturan Tata Tertib DPR.RI Tanggal 27 September 2005.

Keputusan Dewan Perwakilan Rakyat Daerah Provinsi Jambi Nomor 6 tahun 2006 tentang Peraturan Tata Tertib Dewan Perwakilan Rakyat Daerah Provinsi Jambi.

Keputusan Dewan Perwakilan Rakyat Daerah Provinsi Jambi Nomor 11 Tahun 2005 tentang Kode Etik Dewan Perwakilan Rakyat Daerah Provinsi Jambi. 
